\title{
Australian paleoseismology: towards a better basis for seismic hazard estimation
}

\author{
Dan Clark $\left({ }^{1}\right)$ and Kevin McCue $\left(^{2}\right)$ \\ ( $\left.{ }^{1}\right)$ Geoscience Australia, Canberra, Australia \\ $\left(^{2}\right)$ Australian Seismological Centre, Jamison Centre, Australia
}

\begin{abstract}
Probabilistic seismic hazard analyses in Australia rely fundamentally on the assumption that earthquakes recorded in the past are indicative of where earthquakes will occur in the future. No attempt has yet been made to assess the potential contribution that data from active fault sources might make to the modelling process, despite successful incorporation of such data into United States and New Zealand hazard maps in recent years. In this paper we review the limited history of paleoseismological investigation in Australia and discuss the potential contribution of active fault source data towards improving our understanding of intraplate seismicity. The availability and suitability of Australian active fault source data for incorporation into future probabilistic hazard models is assessed, and appropriate methodologies for achieving this proposed.
\end{abstract}

Key words intraplate seismicity - seismic hazard Australia - paleoseismology

\section{Introduction}

On the 27 th of December 1989 a magnitude $M_{L} 5.6$ earthquake near Newcastle NSW shattered the commonly held view that damaging earthquakes do not occur in Australia. This event resulted in the loss of 13 lives and is, to this time, the most destructive and costly natural disaster to have occurred in Australia (e.g., Sinadinovski et al., 2002, table 3-1). While being the most costly, the Newcastle earthquake was certainly not the first damaging event to affect a populated centre in Australia (e.g., 1954 Adelaide event, McCue, 1975; 1968 Meckering and 1970 Calingiri events, Gordon and Lewis, 1980; 1979 Cadoux event, Lewis et al., 1981).

Mailing address: Dr. Dan Clark, Geoscience Australia, P.O. Box 378, Canberra ACT 2601, Australia; e-mail: dan.clark@ga.gov.au
Australia experiences an earthquake of sufficient magnitude to cause structural damage $(M \geq 5.5)$ once every two years on average (McCue, 1990). However due to the very clustered nature of Australia's population, and the continent's large area, most earthquakes are far from populated centres and infrequently cause more than superficial damage.

Australia resides within the Indo-Australian plate, and is classified as a Stable Continental Region (SCR) according to the definition of Johnston et al. (1994) - the landmass is largely unaffected by currently active plate boundary processes, and has not been influenced by significant orogenic or extensional events for tens of millions of years. SCRs worldwide are characterised by very low strain rates, and correspondingly low levels of seismicity relative to active continental regions and plate margin regions. Such areas account for less than one percent of global moment release (Johnston et al., 1994). Consequently, the larger more damaging SRC earthquake events are rare relative to the period of historic observation. This fact poses problems for seismologists undertaking 
probabilistic seismic hazard analyses that rely heavily on the assumption that earthquakes recorded in the past are indicative of where earthquakes will occur in the future - such assumptions underpin the earthquake hazard maps used in the Australian Building Code (AS1170.4, 1993). The historic record of 100200 years is far too short to accurately reflect the long-term activity on the faults that generate these events ( $c f$. Machette et al., 1993). The problem is compounded when it is considered that the largest, least frequent events dominate the moment budget.

Strategies that have been employed to overcome this problem fall into two mutually dependant categories: 1) obtaining a better understanding of the patterns and characteristics of contemporary intraplate seismicity, and 2) extending the historic record by consulting the record of seismicity recorded in the landscape (i.e. paleoseismology). The following sections will examine each of these areas in turn for the Australian context. After a brief introduction to Australian intraplate seismicity and some of its geomorphological ramifications, we present a review of paleoseismological investigation in Australia, and offer a discussion on what has been learnt about Australian seismicity from these studies. The future of active fault source data in providing a better basis for seismic hazard assessment in Australia is also discussed.

\subsection{Australian intraplate seismicity}

Earthquakes in Australia have been monitored with various degrees of completeness since 1888 when the first seismograph was installed. Figure 1 presents an epicentre map of earthquakes with magnitude $M \geq 4$ for the period 1901-2001. The data is from the World Earthquake Database maintained by Geoscience Australia with contributions from university, state and private seismological agencies. The database is probably complete for magnitude $M \geq 6$ since $1901, M \geq 5$ since 1963 and $M \geq 3.2$ since 1995 .

Focal depth control in the database is mostly poor, ostensibly due to a combination of incompletely characterised earth models, and sparse seismograph density. However, some generalisations may be made. With a few notable exceptions (e.g., McCue and MichaelLieba, 1993), earthquakes initiate in the depth range two to twenty kilometres. Within the ancient shield areas of Western and South Australia, and the Northern Territory (e.g., the Achaean Yilgarn, Pilbara and Gawler cratons, and the Pine Creek inlier, $c f$. Palfreyman, 1984) most foci are generally at the shallow end of the range, with some events occurring in the top two kilometres. Two of the larger Australian earthquakes, the $1968 M_{S} 6.8$ Meckering event and the 1988 Tennant Creek sequence (see fig. 1 for location) have calculated hypocentral depths of the order of $6 \mathrm{~km}$ or less (Langston, 1987; Bowman and Dewey, 1991). Hypocentres are more evenly distributed within the range in the predominantly younger rocks (largely Phanerozoic) of Eastern Australia and in Eastern South Australia.

Beyond identification of the depth of the brittle-ductile transition, no attempt has been made to explain these apparently shallow hypocentral depths. However, analysis of shallowcrustal stress measurements from across Australia (e.g. Denham et al., 1979, 1981; Denham and Windsor, 1991; Hillis et al., 1999; Hillis and Reynolds, 2000), and the propensity for shallow rock failure in mines (Max Lee, Australian Mining Consultants Pty Ltd., personal communication), indicates that in the top several kilometres of crust the maximum principal stresses are horizontal, of high magnitude, and are coupled with highly deviatoric stress regimes. Such conditions are likely to be conducive to shallow rupture initiation.

Earthquake fault plane solutions constructed for a selection of larger events are consistent with the stress data, with the majority indicating thrust source mechanisms (Hillis and Reynolds, 2000; Clark and Leonard, 2002; Leonard et al., 2002). Strike-slip mechanisms are locally important in the Flinders Ranges of South Australia, and in Northwest Western Australia. Normal faulting mechanisms are relatively rare; there were two in Southeastern Western Australia (1985 $M_{L} 5.4$ Norseman event; $2001 M_{L} 5.2$ Ravensthorpe event), one in the highlands of Victoria (1966 $M_{L} 5.6$ Mount 


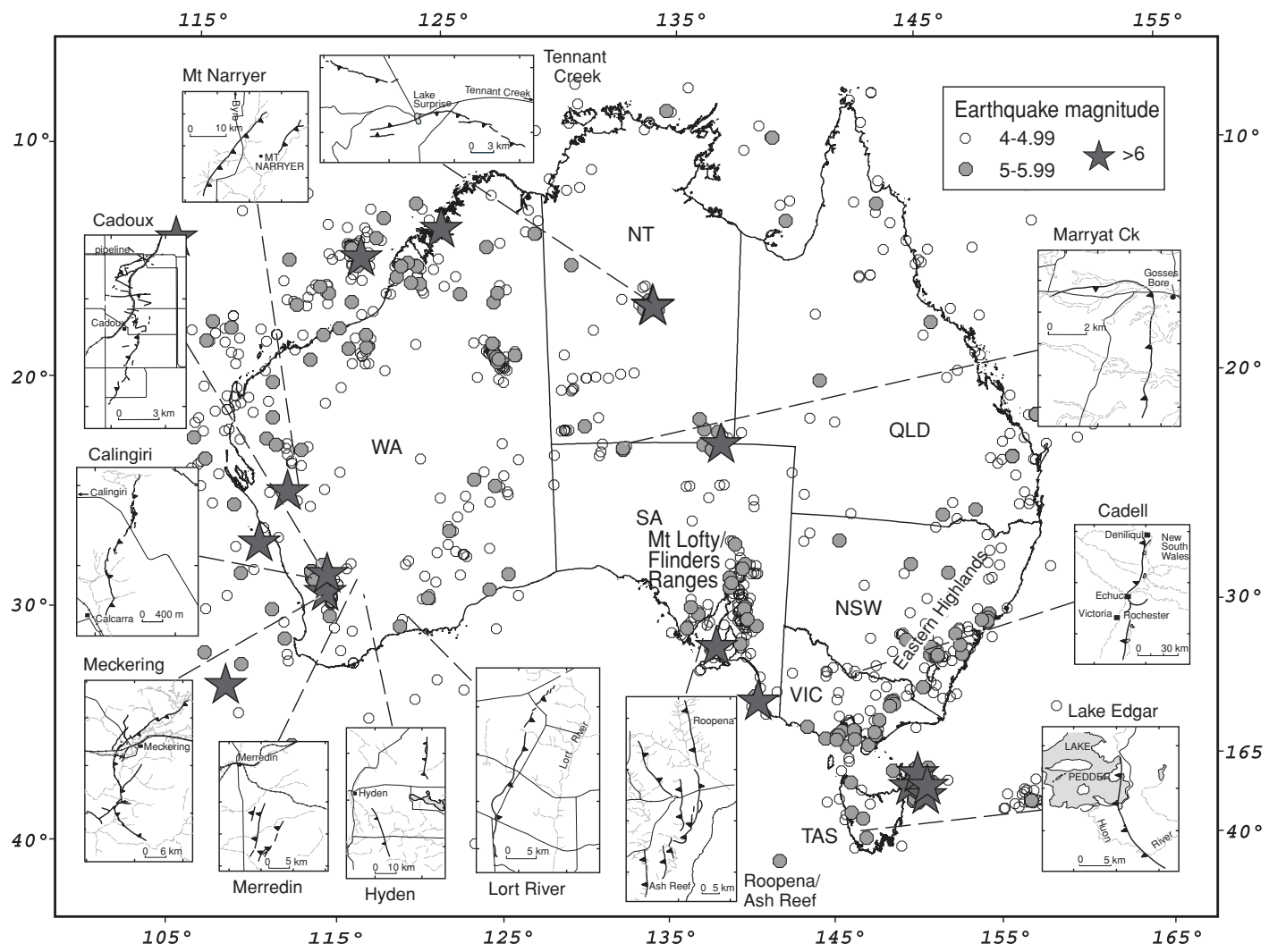

Fig. 1. Seismicity of Australia, 1900-2002, and recent fault scarps (modified after McCue, 2001). Earthquakes relating to the northern margin of the Australian plate have been removed from the image for clarity. Earthquake magnitudes are presented as $M_{L}$ for $M<6$ and $M_{S}$ for $M>6$. WA = Western Australia; NT = Northern Territory; QLD = Queensland; SA = South Australia; NSW = New South Wales; VIC = Victoria; TAS = Tasmania

Hotham event), and another in central west New South Wales (1996 $M_{L}$ 5.1 Range event).

Perhaps the least understood facet of Australian earthquakes is their relationship to the geology. Hypocentre precision estimates are to tens of kilometres, so earthquake events cannot be confidently assigned to known structures, except where events produce a surface rupture (see Section 1.2). Australian epicentres were overlain on various geological and geophysical datasets at a continental scale (McCue et al., 1998) to see if any obvious patterns were evident. The study concluded that no consistent relationships were apparent, which is perhaps not surprising given the complexity of Australian geology and that the earthquake catalogue contains only forty years of complete data for magnitudes down to five.

The possibility that this and other discrepancies are just a function of the short recording period can in part be addressed through paleoseismological investigation. In the next sections we discuss what is known of the geomorphic expression and longevity of features born of earthquake events in Australia. The questions we address are: how much paleoseismological information is currently out there and what is its nature? 


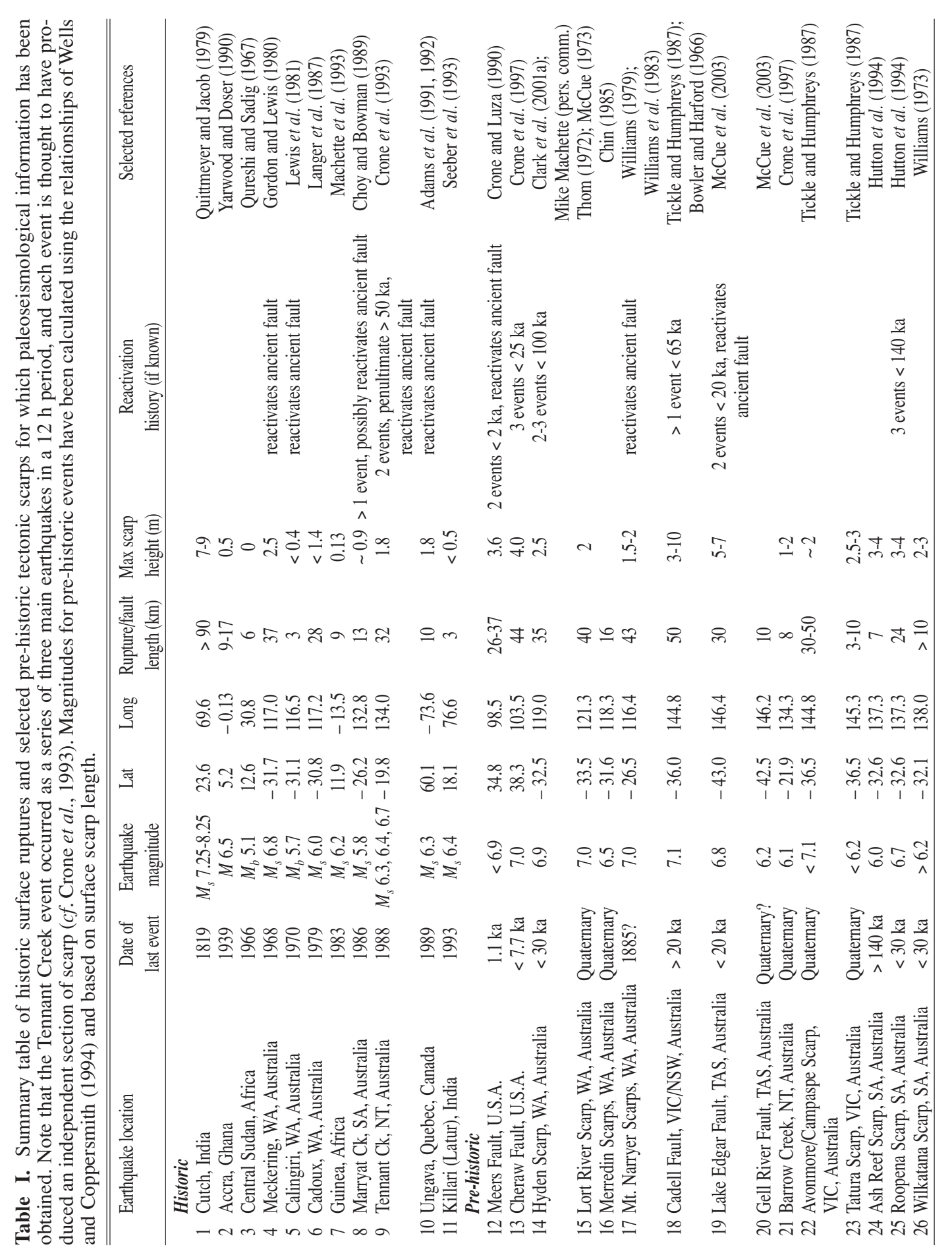




\subsection{Historic fault scarps}

Seven instrumentally recorded earthquakes in Australia are known to have produced surface ruptures (table I). Curiously, all of these earthquakes have occurred in Central and Western Australia, and in the last forty years there were no documented surface rupturing earthquakes in the period between European settlement in 1788 and the 1968 Meckering earthquake.

The magnitude of the earthquakes that produced the seven scarps ranges from $M_{L}(I) 5.6$ to $M_{S} 6.8\left(M_{L}(I)\right.$ is a Richter magnitude equivalent scale based on the felt area or radius of perceptibility, McCue, 1980). Two of these events were smaller than magnitude six, the $1970 M_{L}(I)$ 5.6 Calingiri WA earthquake and the $1986 M_{S} 5.8$ Marryat Creek SA earthquake. The magnitude of the Calingiri earthquake may be an underestimate because in the early seventies there were no wide dynamic range seismographs within $600 \mathrm{~km}$, and all nearby seismographs were saturated. Furthermore, the event occurred at 3:15 a.m. Western Standard Time when most people were asleep, so the radius of perceptibility is probably an underestimate. Its assigned body wave magnitude $\left(m_{b}\right)$ was 5.7.

The surface ruptures relating to these events range from $3.5 \mathrm{~km}$ to $37 \mathrm{~km}$ in length, and 0.4 $\mathrm{m}$ to $2.5 \mathrm{~m}$ in height. All the scarps have a dominant component of reverse displacement, and arcuate thrust geometry ( $c f$. Everingham et al., 1969). In detail, some of the rupture traces are seen to be a composite of thrust and obliqueslip components. For example, the 1979 Cadoux surface rupture comprises northerly oriented thrust segments and easterly oriented strike-slip segments (Lewis et al., 1981). Similar complexity in the Tennant Creek surface rupture has been ascribed to complex interactions between subjacent fault sets in the subsurface (Crone et al., 1993).

The historic and instrumental record suggests that there have been at least $14 M>6$ onshore earthquakes in the last 100 years, yet we know of only seven surface ruptures that can be related to these recorded events. It is suggested that this can to a large degree be related to the sparsely populated nature of Australia - it is very likely that there are more 'historic' scarps to be discovered. The largest onshore event to be recorded in Australia, the 1941 Meeberrie WA earthquake of magnitude $M_{S} 6.9$, is a prime candidate. How recognisable these features may be in the landscape depends upon many factors, including the local rate of degradation of topography.

\subsection{Degradation of historic scarps}

All seven historic Australian surface ruptures occur in areas with little appreciable relief and low rainfall. The topography in the Meckering-Calingiri-Cadoux area comprises a flat to rolling landscape punctuated by low, bare, rounded granite hills. The average annual precipitation is in the order of $400 \mathrm{~mm}$, which occurs mainly in the wintertime as showers associated with frontal systems (Bureau of Meteorology, 2001). Agriculture is the main land use in the area, with the result that up to $90 \%$ of the ground surface has been cleared of its native vegetation and tilled. In general, the soil profile consists of a thin layer of transported sandy soil overlaying a duricrust layer (dominantly ferricrete), which in turn overlays weathered bedrock (Gordon and Lewis, 1980). Without anthropogenic intervention, the scarp preservation potential within this soil profile might be expected to be relatively high, at least on a time-scale of decades.

This is certainly the case for the $\sim 100 \mathrm{~m}$ long section of the 1968 Meckering surface rupture that was fenced off as a geological monument shortly after the event. The original scarp height at this location was in the order of $1.5 \mathrm{~m}$ (fig. 2a). Thirty-four years later some of the fine structural detail has been lost, but the scarp remains a remarkable feature in the landscape (fig. 2b). This good state of preservation is in a large part due to the resistant nature of the ferricrete horizon defining the scarp at this site. Elsewhere, farming activities, principally ploughing, have destroyed all evidence for the former existence of the scarp. This is also the case for the Calingiri and Cadoux scarps.

The Marryat Creek and Tennant Creek scarps occur in deeply weathered arid lands of 

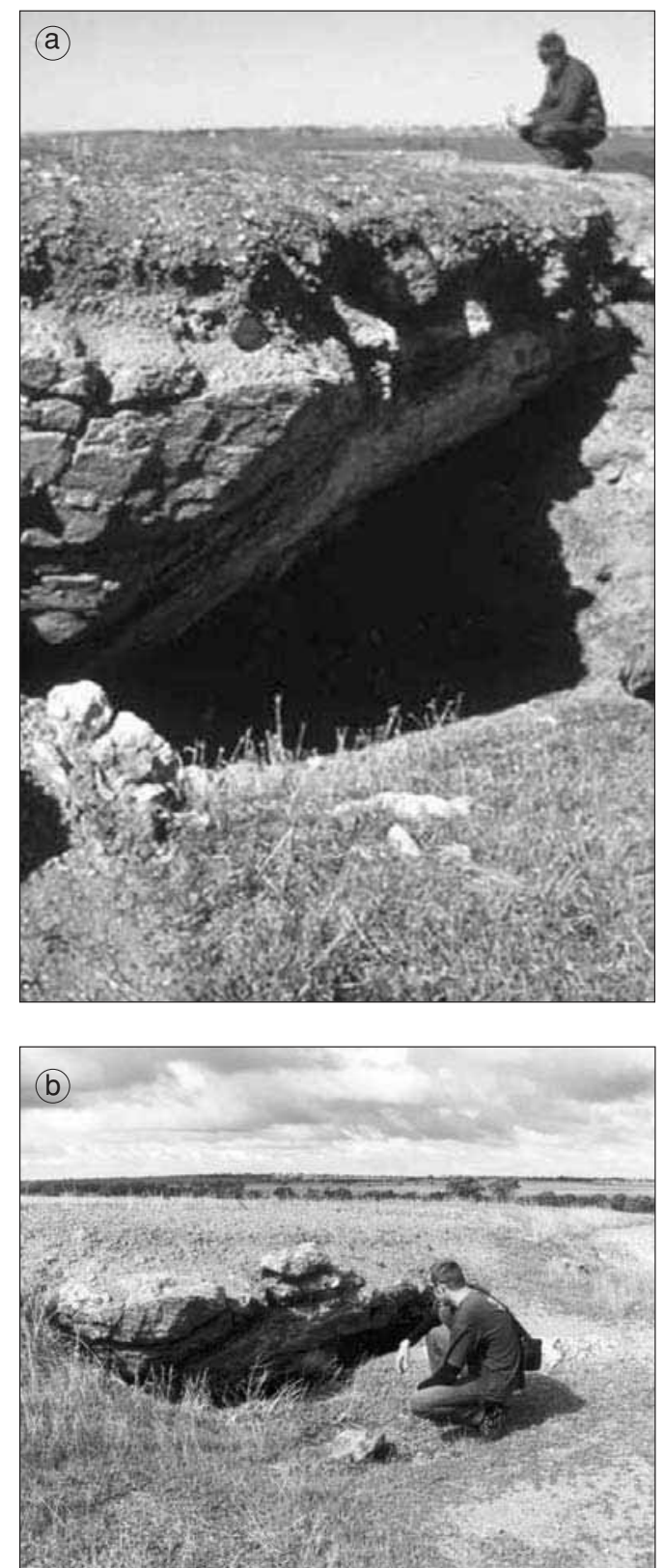

Fig. 2a,b. Images of a section of the 1968 Meckering scarp, looking south. a) Captured in 1970, and b) captured in May 2002. Scarp preservation has been assisted by the durable ferricrete and weathered bedrock layer exposed in the hangingwall. Note the rolling topography of farmland in the background. very low relief. Bedrock outcrop is very rare. The average annual precipitation is less than $300 \mathrm{~mm}$, most of which is delivered in the summer months during often violent storms (Bureau of Meteorology, 2001). In contrast to the Meckering area, the soil profile in these regions is characterised by up to tens of metres of alluvium and colluvium overlying deeply weathered bedrock (Coats, 1963; Connor, 1978; Machette et al., 1993). The ground surface is sparsely populated with woody herbs and grasses, typically of the genus' Acacia and Spinifex. During dry periods, over-grazing by cattle and rabbits leaves the ground surface very prone to erosion by wind and during storm events. The scarp preservation potential within this soil profile might be expected to be relatively low because of the significant depth to durable bedrock.

This suggestion is apparently borne out by repeat topographic data collected from the Marryat Creek scarp in 1986 and 1990. Comprehensive levelling data collected soon after the event in 1986 record a maximum vertical offset of $0.9 \mathrm{~m}$ (Bowman and Barlow, 1991), whereas four years later a maximum offset along the same section scarp of only $0.6 \mathrm{~m}$ was measured (Machette et al., 1993). Despite this rapid degradation, Machette et al. (1993) reported that scarps, small ground ruptures and other surficial features were still evident along much of the rupture length after 4 years. However, erosion and the action of cattle had destroyed most evidence for lateral slip and other fine structural features. A similar intensity of scarp degradation was reported from the Tennant Creek scarp two years after its formation (Crone et al., 1993). Due in large part to extreme remoteness, neither scarp has been visited recently.

The above discussion has important implications for where paleoscarps might be preserved in Australia. In general, the arid regions of Australia are deeply weathered and bedrock is often covered with a significant veneer of unconsolidated sediment. Scarp preservation potential in these areas is low, especially where a significant portion of the local rainfall is delivered by intense storms. The Mount Narryer scarps in Western Australia (fig. 1) may be 
a good example. Available evidence suggests that the topographic expression of these scarps has been erased in under one hundred years (see next section for more details; Williams, 1979). That scarps do not appear to be preserved in deeply weathered areas also implies very low long-term slip rates on individual structures, else bedrock would be brought to the surface and tectonic relief maintained. In contrast, regions where shallow sediments overly a duricrust and/or bedrock appear to have relatively good scarp preservation potential. The documented occurrence of paleoscarps in Southern Western Australia (e.g., Lort River, Hyden, Merredin), and on the Eyre Peninsula in South Australia (e.g., Ash Reef, Roopena) supports this observation.

\section{Paleoseismological investigations in Australia}

Figure 1 presents a map of Quaternary and selected historic fault scarps that have been investigated in more than cursory detail. Characteristics of the activity on each feature are summarised in table I.
The first trenching investigation of a suspected Quaternary fault in Australia was in 1973 (McCue, 1973). The objective of the study was to determine whether the then recently identified Lort River scarp (Thom, 1972) in Western Australia was a fault scarp, or related to fluvial processes. The investigation arose as part of the considerable interest in determining how common surface ruptures were in Australia following the Meckering 1968 surface rupture.

Evidence to suggest that the $40 \mathrm{~km}$ long and $2 \mathrm{~m}$ high Lort River scarp was indeed a fault scarp, and a relatively recent addition to the landscape, was provided by aerial photography over the area. Several small streams are clearly truncated, and have ponded against the scarp. The trench $\log$ produced by the study clearly shows that the scarp relates to an easterly-dipping reverse fault with about $2 \mathrm{~m}$ of vertical displacement (fig. 3; McCue, 1973). The former ground surface, rich in laterite nodules and likely of Tertiary age (cf. Thom et al., 1977), could be traced back under the overthrust block. No attempt was made by the investigators to take samples for dating. However, the thick accumulation of unconsolidated fine white sand overlying

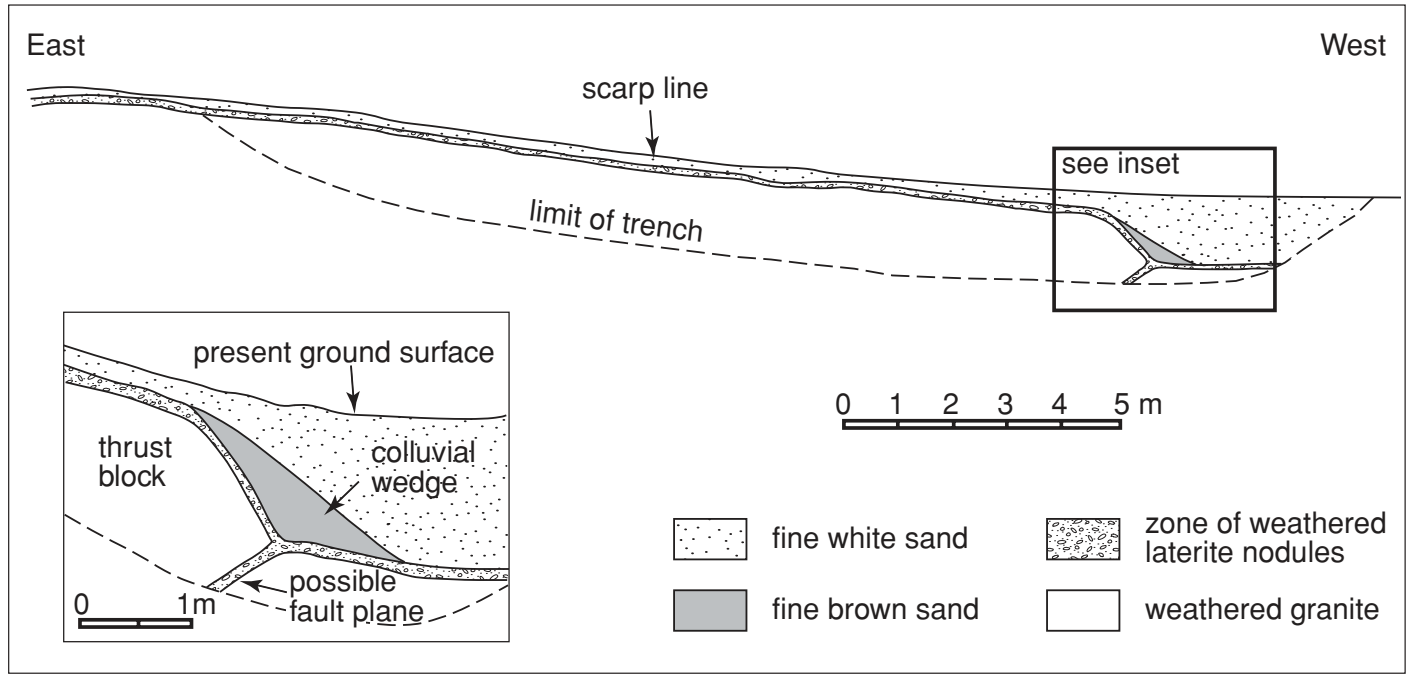

Fig. 3. Sketch of the ground profile revealed on the southern wall of a trench excavated across the Lort River Scarp in Western Australia (modified after McCue, 1973). 
the scarp suggests an age of Late Pleistocene or older.

Several years later, two northeasterly trending fault scarps were identified in the Mount Narryer region of Western Australia during routine geological mapping (Williams, 1979; Williams et al., 1983). The westerly scarp is approximately $30 \mathrm{~km}$ long and has little associated relief. The easterly scarp is $\sim 13 \mathrm{~km}$ long and was reported to have a west-side-up relief of around $1.2 \mathrm{~m}$. Both scarps are extremely degraded, and were identified on the basis of the prominent vegetation lineaments associated with them. It was originally though that the scarps might relate to the 1941 Meeberrie earthquake as the epicentre for this event occurs less than $50 \mathrm{~km}$ to the south west - less than the uncertainty in the epicentre location. However, the results of dendrochronological analysis of Acacia sp. trees growing in colluvium related to the scarp were used as evidence to link the scarps with reports of a significant earthquake which was felt in the Geraldton area in 1885 (Williams, 1979). It has been estimated from felt reports (Everingham and Tilbury, 1972) that the local magnitude of the 1885 event was in the order of 6.5. Because of the sparse population of Western Australia at that time, the epicentral location of the earthquake is very poorly constrained, so a definitive link cannot be made on seismological grounds.

In the early nineties Australia became the target for integrated studies of surface-faulting earthquakes in stable continental regions because half of the known historic cases of surface-rupturing earthquakes in such regions of the world have occurred in Australia. As mentioned in the previous section, investigations were conducted of the surface ruptures produced by the 1988 Tennant creek earthquake sequence (Crone et al., 1993, 1997), the 1986 Marryat Creek event (Machette et al., 1993; Crone et al., 1997), and the 1968 Meckering event (Crone et al., 1997). Some evidence was revealed at the former two localities for pre-historic surface rupturing earthquakes at the site of the historic events.

Two trenches excavated across the western arm of the main arcuate Tennant Creek scarp (Crone et al., 1993) revealed the presence of a Late Quaternary scarp buried by aeolian sand deposits. The vertical relief on this prehistoric scarp is at least equal to that of the contemporary scarp at those sites $(\sim 0.8 \mathrm{~m})$, which formed consequent to the second earthquake event in the sequence $\left(M_{S} 6.4\right.$, Choy and Bowman, 1989). This scarp was not reactivated during the 1988 events, and could not be directly dated. However, thermoluminescence dating of the lower layers of the overlying sand deposits suggests that accumulation of this sediment began $\mathrm{ca}$. 50 ka (Crone et al., 1993; Hutton et al., 1994).

Most evidence for prehistoric (Pleistocene) movement on the Marryat Creek scarp has been removed by erosion (Machette et al., 1993). However, trenching revealed that the contemporary scarp exploits a 10-15 m wide zone of pervasive shearing and alteration in the granite bedrock. Only selected planes in this zone were reactivated in the 1986 event, suggesting that the earthquake reactivated faults that probably have a long history of recurrent movement. A 2-5 $\mathrm{m}$ high linear ridge at the southern end of the scarp may relate to a portion of this postulated movement (McCue et al., 1987; Crone et al., 1997). The age of the oldest surficial sediments overlying inactive strands of the fault zone, which provide a minimum age for penultimate surface faulting, was estimated visually to be in the order of $100 \mathrm{ka}$ (Machette et al., 1993; Crone et al., 1997).

A cursory investigation of a trench excavated through the Meckering scarp as part of a symposium on «Recent Intraplate Seismicity Studies» (Gregson, 1990) revealed no obvious evidence for earthquake-related features predating the 1968 event (Crone et al., 1997). However, Gordon and Lewis (1980) noted that parts of the 1968 ruptures are marked by abundant quartz fragments, providing circumstantial evidence that the scarps exploit an ancient mineralised fault zone. Further evidence that the scarp follows an ancient line of weakness is provided by the course of the Mortlock River, which has an arcuate shape which parallels the 1968 scarp for $12 \mathrm{~km}$ at a distance of about $1.5 \mathrm{~km}$ (Gordon and Lewis, 1980). This geometry was established prior to the 1968 surface rupturing event. The Meckering trench was not logged or interpreted.

International interest in Australia's Quaternary fault scarps continued in the late nineties with 
paleoseismological investigations being conducted over the Hyden scarp in Western Australia, and the Roopena scarp in South Australia (Crone et al., 2003). The detailed results of these studies have not yet been published, but preliminary results of optically stimulated luminescence dating suggest at least two surface faulting earthquakes occurred on the Hyden scarp, at 30 and $50 \mathrm{ka}$, and three surface faulting earthquakes occurred on the Roopena scarp, at 30, 100, and 150-200 ka (Mike Machette, pers. com.). Estimates of $\sim 140 \mathrm{ka}$ were made for the age of basal sediments within small scarp-related lakes occurring at the foot of the Roopena scarp (Hutton et al., 1994), which is consistent with the age of the oldest event postulated by Crone et al. (2003). The total vertical displacement across the $30 \mathrm{~km}$ long Hyden scarp, distributed amongst the two events, is in the order of $2.5 \mathrm{~m}$. Approximately $3.9 \mathrm{~m}$ of vertical displacement must be distributed amongst the three postulated Roopena scarp events ( $c f$. Miles, 1952; Dunham, 1992). There is also the suggestion of significant lateral displacement on the $28 \mathrm{~km}$ long Roopena scarp.

The $30 \mathrm{~km}$ long and more than $5 \mathrm{~m}$ high Lake Edgar Fault scarp in Southwest Tasmania was identified as a fault scarp in the 1960's (Carey and Newstead, 1960; fig. 1). The first trench excavated over the scarp was part of an investigation into the feasibility of the Lake Edgar Dam project (Roberts et al., 1975). However, it was not until the nineties that a paleoseismological investigation was conducted (McCue et al., 1996; Van Dissen et al., 1997; McCue et al., 2003). The paleoseismological study re-occupied the original dam project trench, which was excavated near the centre of the scarp where the vertical displacement is in the order of $2.5 \mathrm{~m}$. The trench excavation provided evidence that the fault had generated at least two surface-faulting earthquakes. Geomorphological evidence was used to suggest that these events were of Quaternary age, the youngest event having occurred within the last 20000 years. Each event is associated with a vertical displacement in the order of $2.5 \mathrm{~m}$. An attempt to provide better constraint on the time of faulting using the radiocarbon technique proved unsuccessful.

Despite the apparent age of the Lake Edgar scarp, and a high local annual rainfall by
Australian standards $(\sim 2000 \mathrm{~mm}$, Bureau of Meteorology, 2001), the feature is still a sharp break in the land surface (McCue et al., 2003). This characteristic can in a large part be attributed to the peat-dominated soils displaced by the faulting ( $c f$. Williams, 1977, Kiernan, 1990). The competence of these materials is demonstrated at the site of the McCue et al. (2003) investigation, where the walls of the $4 \mathrm{~m}$ deep trench have remained standing for 30 years, even through the trench is permanently half-filled with water.

In mid-2001, a consortium led by Mike Dentith from the University of Western Australia retrenched the Hyden scarp $4 \mathrm{~km}$ to the south of the Crone et al. (2003) trench (Clark et al., $2001 \mathrm{a}, \mathrm{b})$. The soil profile at the site of the trench consists essentially of a mantle of aeolian sand overlying a ferricrete layer that had been disrupted by reverse faulting (fig. 4). The vertical displacement across the various fault strands depicted in fig. 4 is $\sim 2.5 \mathrm{~m}$. It is apparent that subsequent to the last faulting event, and prior to the deposition of the sand, the ferricrete surface has undergone significant erosion. Stratigraphic evidence that might have revealed the number of surface faulting events that the structures in the trench reflect has therefore been removed. However, preliminary optically stimulated luminescence ages on samples from the base of the sand layer suggest that the last faulting event at this locality occurred prior to $90 \mathrm{ka}$. It is therefore not clear at this early stage of the study how the structures revealed in this trench relate to those exposed in the Crone et al. (2003) trench.

There is a wealth of paleoseismological information yet to be recovered from the geomorphological record of Australia. Many references have been made in Australia's geologic and geomorphic literature to post-Tertiary faulting (e.g., Victorian scarps, Hills, 1960 - Cadell Scarp, Harris, 1938 and Bowler and Harford, 1964, 1966 Australian scarps in general, Twidale, 1968 Wilkatana Scarp and other Flinders Ranges and Mount Lofty Ranges scarps, Williams, 1973 and Sandiford, 2003 - Merredin Scarps, Chin, 1985 Gell River Fault, Roberts et al., 1975 and McCue et al., 2003 - Tatura Scarp, Tickell and Humphrys, 1987 - Palmer Fault, Bourman and 


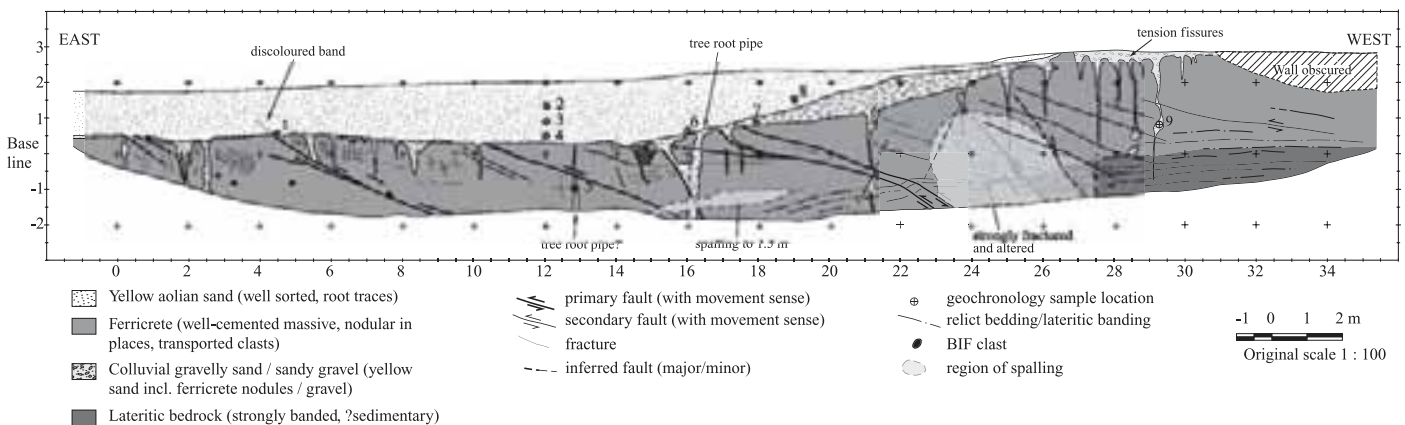

Fig. 4. Grid map of the ground profile revealed on the southern wall of a trench excavated across the Hyden scarp in Western Australia (after Clark et al., 2001b).

Lindsay, 1989 - Avonmore Scarp, Cherry and Neivandt, 1995 - Barrow Creek Scarp, Crone et al., 1997). These accounts generally focus on observations of fault scarps, changes in drainage such as ponding against scarps, and stream diversion, and make no attempt to associate the features with pre-historic earthquakes.

\section{Discussion: towards a better basis for seis- mic hazard assessment}

\subsection{What has been learned about Australian seismicity, and surface faulting earthquakes in particular?}

\subsubsection{Magnitude versus scarp length and height relations}

The largest known earthquake to produce a surface rupture in Australia in historic times was the $1968 M_{S} 6.8$ Meckering event, which produced a scarp $37 \mathrm{~km}$ long. Similarly, the $1988 M_{S}$ 6.3-6.7 Tennant Creek events produced approximately 32 $\mathrm{km}$ of surface rupture. There are pre-historic scarps yet to be fully characterised that are significantly longer than those produced by historic surface rupturing earthquakes (up to $50 \mathrm{~km}$, table I), and presumably relate to larger or multiple events.

Relationships were developed for estimating the magnitude of pre-historic events based upon the lengths and heights of the seven Australian historic scarps (McCue, 1990). Because of the small sample-space these relationships are not statistically robust, and must therefore be treated with caution. However, the McCue (1990) relationships are comparable to similar relationships derived from reverse faults worldwide (e.g., Wells and Coppersmith, 1994; fig. 5, table I), and furthermore appear to be indicative of several characteristics that distinguish Australian surface ruptures, or at least those from the central and western regions of Australia.

There is some indication that for a given event magnitude, surface ruptures in Western and Central Australia tend to be longer and involve greater displacements than those in the world data set. This finding is counter-intuitive, as one might expect that rupture planes in intraplate areas would be compact because of the inherent strength of cold, thick crust. The January $2001 M_{W} 7.6$ Bhuj earthquake is perhaps an extreme example of a compact rupture, being only $40 \mathrm{~km}$ long by $36 \mathrm{~km}$ deep (Arch Johnston, personal communication).

The reason why this might be so has not been studied in detail and is largely beyond the scope of this contribution to answer. However, it is tempting to speculate that a combination of high shear stress at shallow depth (as suggested in Section 1.1) combined with the stress regime becoming less compressive with depth (there is an indication from in situ stress data that this might be the case, Hillis and Reynolds, 2000; Richard Hillis personal communication, 2002), might be responsible. In this scenario, hypocentre nucleation would be favoured at shallow depth, and downward propagation 

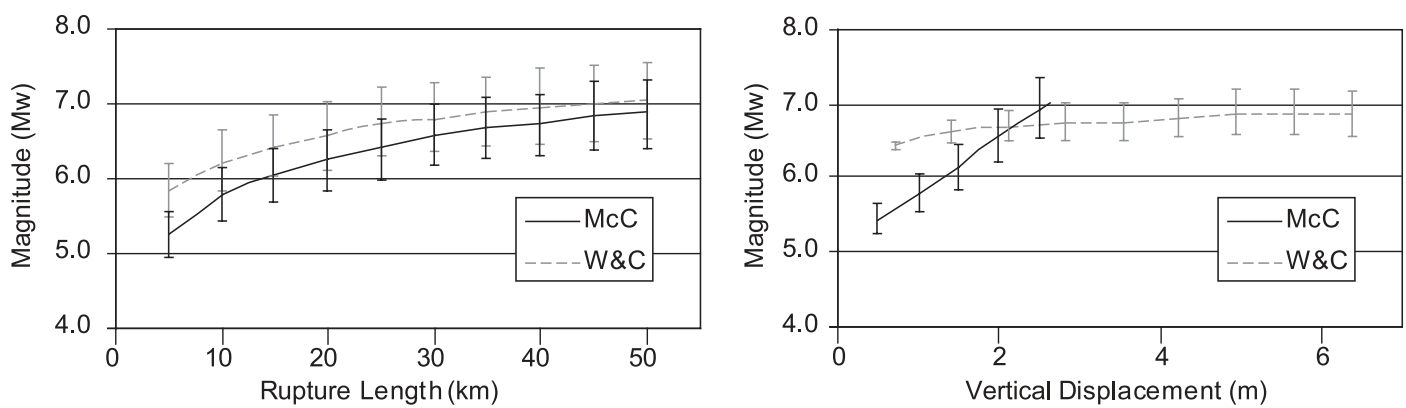

Fig. 5. Comparison of McCue (1990) and Wells and Coppersmith (1994) relationships tying rupture length versus magnitude and displacement versus magnitude. Note that McCue (1990) uses $M_{L}$ for magnitudes below 6.0, and $M_{S}$ for those above, which approximates $M_{W}$. A fault dip of 45 degrees was assumed in order to convert displacement in the Wells and Coppersmith (1994) relationship to scarp height. Error bars are $2 \sigma$.

of ruptures along a given structure would be hindered by a progressively less favourable stress regime. Alternatively, a barrier to downward propagation of a shallowly nucleated rupture might be provided by the gross geological structure. For example, a seismic reflection profile across the seismogenic zone in south western Western Australia (Dentith et al., 2000) revealed that shallowly dipping near-surface structures favourably oriented for failure in the prevailing east-west stress field sole into a sub-horizontal detachment surface at $8 \mathrm{~km}$ depth.

Because there have been no historic surface ruptures in Eastern Australia it is not possible to estimate the magnitude of the events which formed pre-historic scarps with any confidence. However, if one were to apply magnitude versus rupture length relationships of the kind presented by McCue (1990) and Wells and Coppersmith (1994) to the longest known scarps (e.g., Cadell, Avonmore) events of around magnitude seven, or slightly above, are obtained (table I). There are no indications in the known geomorphic record that events of a magnitude discernibly greater than this have occurred.

\subsubsection{Reactivation and recurrence}

Several of the scarps discussed in previous sections preserve evidence for multiple Quaternary displacement episodes (table I). In addition, there is evidence that many historic and pre-historic surface ruptures exploit ancient fault systems, or zones of weakness. The Lake Edgar Fault is perhaps the best example of both these characteristics. Prior to its two Quaternary reverse faulting episodes (McCue et al., 2003) the structure is thought to have been active in the Paleozoic as a strike-slip fault, with more than $12 \mathrm{~km}$ of right lateral slip (Carey and Newstead, 1960, Roberts et al., 1975). Similarly, abundant quartz float in the vicinity of the Meckering and Calingiri surface ruptures was taken as evidence that the ruptures occurred along lines of ancient weakness (Gordon and Lewis, 1980).

Direct evidence for reactivation was seen in one of the two trenches excavated across the Marryat Creek scarp, where multiple fault strands not activated in the 1986 event were recorded within the Proterozoic crystalline bedrock underlying Quaternary sediments (Machette et al., 1993). These older fault strands do not displace the Quaternary sediments, and are not associated with significant relief on the bedrock/sediment interface. An attempt to provide a minimum age for the penultimate event by dating the lowermost Quaternary sediments (based upon $\mathrm{Ca}++$ accumulation in the soil) produced equivocal results, but with the suggestion that the sediments began accumulating in the order of $100 \mathrm{ka}$.

Parts of the 1988 Tennant Creek scarp also show direct evidence for pre-historic surface 
faulting. The $0.8 \mathrm{~m}$ high buried scarp exposed in two trenches excavated across the western Lake Surprise scarp was interpreted to reflect a reactivation of a pre-existing fault zone (Crone et al., 1993, 1997). Luminescence dating of unfaulted sediments overlying the paleoscarp, suggest that it formed more than $50 \mathrm{kyr}$ before the 1988 scarp (Crone et al., 1993). In apparent contradiction to the paleoseismological evidence, there is anecdotal historical evidence to suggest that one or two large $(M>6$ ?) earthquakes occurred in the vicinity of Tennant Creek as recently as 1883 (McCue, 2001). However, it is not known whether these events activated parts of the future 1988 scarp, or occurred on another as yet undiscovered fault in the region.

Although the data are still few, there appears to be a pattern emerging where surface rupturing earthquakes in Australia occur preferentially on a few pre-existing and often ancient faults. These faults seem to be quiescent for long periods of time between surface rupturing events, in the order of tens of thousands to a hundred thousand years or more (cf. Crone et al., 1993, 1997; Johnston et al., 1994, figs. 4-8). The preliminary data from the Hyden and Roopena scarps (Crone et al., 2003; Mike Machette personal communication, 2002) support this interpretation. The data on reactivation of Australian surface rupturing faults are too few to meaningfully assess whether they demonstrate the successive occurrence of events of similar displacement, generating 'characteristic' magnitude earthquakes ( $c f$. Schwartz and Coppersmith, 1984). However, paleo- and historic scarps of equal height at Tennant Creek (Crone et al., 1993), and evidence that the two Quaternary events on the Lake Edgar scarp both produced displacements of $2.5 \mathrm{~m}$ (McCue et al., 2003), suggest that the concept of 'characteristic event' may have some merit in the Australian context.

It is noteworthy that while it appears that long time intervals separate surface rupturing earthquakes Australia-wide, the expression of this seismicity in the landscape is very different from east to west. Western and Central Australia is characterised by very low relief (e.g., fig. 2b) and modest fault scarps that relate to one, or only a few events (e.g., Crone et al., 1993, 1997; Machette et al., 1993; Clark et al., 2001a,b). The indication is that after a limited number of events, the fault systems lock-up and seismicity migrates elsewhere. In contrast, the eastern highlands in Victoria and New South Wales, and the Mount Lofty and Flinders Ranges regions of South Australia, are characterised by scarps with much greater relief and upon which many events are likely to have occurred (e.g., Twidale, 1968; Tokarev et al., 1998; Sandiford, 2003). This is a fundamental property of Australian seismicity which is yet to be satisfactorily explored. The implications for seismic hazard assessment are obvious, and are further discussed in a following section.

\subsubsection{Segmentation}

There is no conclusive evidence that Australian intracratonic faults rupture in a segmented fashion. However, several lines of circumstantial evidence, including both geometric/geologic and seismological arguments, suggest that segmented behaviour may occur on a limited number of fault systems. For example, Crone et al. (1993) postulate that the Tennant Creek Fault System is capable of segmented behaviour. These authors suggest that the topographic low known as Lake Surprise, which coincides with an area where the 1988 net cumulative offset was small, reflects a segment or rupture boundary in the sub-surface. The discovery of evidence for prior surface rupturing on only one part of the 1988 scarp may reflect the postulated segmental behaviour.

It is noteworthy that the 1970 Calingiri surface rupture occurred $70 \mathrm{~km}$ to the northwest of the 1968 Meckering rupture. The dominant structural grain in the area is NW-SE (e.g., Myers and Hocking, 1998; Whitaker and Bastrakova, 2002). Hence, it is conceivable that these localities both occur on a single structural discontinuity, which ruptures in a segmented fashion. A similar pattern is potentially emerging at present from the Cadoux area, $90 \mathrm{~km}$ to the northeast of Meckering. Following the 1979 Cadoux surface rupture seismicity in the area rapidly decayed to a background rate marginally higher than before 1979 . This period of relative quiescence was broken in September 2001 by an $M_{L} 5.0$ earthquake, located less than $30 \mathrm{~km}$ to the NW of the Cadoux rupture, again along the regional structural grain ( $c f$. Myers and 
Hocking, 1998; Whitaker and Bastrakova, 2002). Since that time, over 18000 earthquakes have been recorded in the area by Geoscience Australia (Leonard, 2002). Four of these events have been of magnitude five or greater, but none have produced a known surface rupture. The epicentres of these events describe a trend to the northwest of the September 2001 epicentre, again parallel to the regional structural grain.

The geometric alignment of discrete pre-historic scarps can also be suggestive of segmental rupture behaviour. For example, the Gell River Fault lies $40 \mathrm{~km}$ to the north along the strike of the Lake Edgar Fault. The intervening ground is characterised by an abundance of ultramafic rocks, which McCue et al. (2003) postulate may act as a rupture barrier. The authors suggest that this lithological boundary could force the Lake Edgar and Gell River faults to rupture independently.

In the Echuca area of Northern Victoria exist three collinear but separately mapped faults. South to north they are the Mount Ida/Colbinabbin, Echuca South and Cadell faults (Bowler and Harford, 1966; Cochrane et al., 1995). The latter two are associated with Quaternary scarps. The Cadell Fault has the larger vertical maximum displacement of about $10 \mathrm{~m}$, compared to 3-4 m for the Echuca South scarp. Very little is known about the rupture history of these structures, including whether they rupture independently or together. The difference in scarp height would suggest that the former possibility is typically the case, but simultaneous rupture cannot be excluded.

The above discussion provides an indication that fault segmentation is a phenomenon that should be considered in the Australian context. At present the data are too few, and the links too circumstantial, to draw conclusions that may be regarded with any confidence.

\subsection{Comparison of the Australian setting with surface rupturing SCR earthquakes else- where}

Few SCR faults have been studied in detail, and only eleven worldwide are known to have produced historic surface ruptures, the most recent being the $1993 M_{W} 6.2$ Killari (Latur) event in India (table I). Discussions of Australian surface ruptures in the context of known surface ruptures in other SCR regions have been presented by Crone et al. (1993, 1997), Machette et al. (1993) and Johnston et al. (1994). Although conclusions are based upon only a few faults, consistent patterns are emerging.

Quaternary surface ruptures on SCR faults often exploit ancient faults or fault zones. Paleoseismological investigations of many Australian fault scarps (table I), the Meers Fault in the U.S.A. (Crone and Luza, 1990), and the Ungava Fault in Canada (Adams et al., 1991, 1992), reveal the presence of pre-existing fault strands that were not activated during the latest surface rupturing event.

SCR faults are also characterised by very low long-term slip rates (e.g. Crone et al., 1997) reflecting the low strain rates in SCR crust (Johnston et al., 1994). Evidence from the Meers (e.g., Crone and Luza, 1990) and Cheraw faults (Crone et al., 1997) in the U.S.A. suggest that activity is also highly episodic, with periods of activity numbering one or two events being separated from prior activity by intervals that may be up to $100 \mathrm{kyr}$ or more. The amazing sequence of three surface rupturing earthquakes in eleven years (1968-1979) in the southwest of Western Australia suggests that episodic activity might also be the norm in Australia. However, more paleoseismological information is required to be confident of this interpretation, as there is some indication, proposed in this review, that faults in Central and Western Australia are abandoned after one or two surface rupturing events.

A characteristic that is particularly pertinent for hazard assessment is that SCR surface rupturing faults are not typically associated with historic seismicity. The Tennant Creek, Marryat Creek, Ungava and Killari events occurred in areas of low perceived seismic hazard (e.g., GSHAP report, Giardini, 1999), revealing the limitations of relying solely on the record of instrumentally recorded seismicity for hazard assessments. Furthermore, because SCR events are infrequent, and often not flagged by contemporary seismicity, the populations of SCR regions are generally poorly prepared, so even relatively small events can and have been extremely damaging (e.g., the 1989 Newcastle 
event and the 1993 Killari event). The hazard is compounded by low attenuation of seismic energy in continental interiors (e.g., Hanks and Johnston, 1992). For example, it has been calculated that an earthquake in the New Madrid seismic zone of the Eastern U.S.A. may have up to twenty times the damage area than a comparable event in San Francisco (Hamilton and Johnston, 1990).

The $2001 M_{W} 7.6$ Bhuj event in India acts as a warning for those attempting to reconstruct histories of seismicity on SCR faults from palaeoseismological information. That the rupture ensuing from this large event did not break the ground surface, nor even approach within $8-9 \mathrm{~km}$ of the surface (Arch Johnston, personal communication) casts doubt on the validity of all estimates of paleoseismicity based upon fault scarp length and height in SCR regions ( $c f$. McCue, 1990; Wells and Coppersmith, 1994).

\subsection{The future: improving seismic hazard assessment}

The recognition that geologic data from active faults can provide an important input to probabilistic seismic hazard analysis is well established. The current hazard maps for the Western United States (Frankel et al., 1996), and for New Zealand (Stirling et al., 1998, 2002), incorporate 500 and 350 well-quantified active faults as earthquake source zones respectively. The Stirling et al. models in particular show an overwhelming dominance of active fault sources over distributed seismicity sources in controlling the hazard for return periods of 475 and 1000 years.

The methodology underpinning the incorporation of geologic data into the hazard modelling process is reasonably robust for plate margin areas where slip rates on the major faults are large and the recurrence intervals for significant or 'characteristic' ( $c f$. Schwartz and Coppersmith, 1984) events are in the order of hundreds of years. However, applying these methodologies to SCRs, with very low slip rates and return periods on active structures in the tens of thousands of years, has proved more problematic. Several different approaches have been adopted in the Central and Eastern United States in order to allow for a contribution to the hazard from active intracratonic faults (e.g., EPRI, 1988; Frankel, 1995; Frankel et al., 1996). In the New Madrid area and the Wabash Valley in Southern Indiana and Illinois, the geometry of faulting is not well characterised and no surface ruptures are known. The recurrence rates for large events in these areas has been estimated based upon paleoliquefaction studies (e.g., Johnston and Schweig, 1996; Obermeier et al., 1992), while a characteristic magnitude event is derived from historical data (e.g., Johnston, 1996a,b). In the hazard modelling process, rupture areas are synthesised using semi-empirical models and the constraints imposed by the geologic data. The combination of $\sim 500$ year recurrence intervals and characteristic magnitude events in the order of 7.5 to 8.0 results in these features contributing significantly to the hazard for the longer return periods (e.g., 1000 and 2500 years, Frankel et al., 1996).

Where Holocene fault scarps are known, for example the Meers Fault in Southwestern Oklahoma ( $c f$. Crone and Luza, 1990) and the Cheraw Fault in Eastern Colorado ( $c f$. Crone and Machette, 1995), maximum magnitude events are derived from the fault length using relations such as those of Wells and Coppersmith (1994). Recurrence intervals are based on geologic measurements of slip rates. The recurrence interval is perhaps the most critical parameter deciding the hazard posed by the active fault source. For example, the Meers Fault has an estimated return time for its 'characteristic' event of 4000 years (Crone and Luza, 1990), and so makes very little contribution even to the 2500 year return time hazard (Frankel et al., 1996).

The most recent probabilistic seismic hazard analysis of the whole Australian continent was published in 1995 (AS1170.4; McCue et al., 1998). This study does not include geologic data from active fault sources, and so relies fundamentally on the assumption that the previously recorded distribution of seismicity is indicative of where earthquakes will occur in the future. In Australia, and in other intracratonic regions worldwide, this approach has 
proved to be unreliable for the larger events. This is mainly due to the order of magnitude difference between the time interval separating $M>6$ events in a given region compared to the time interval over which seismicity has been recorded. As the database of paleoseismological information grows in Australia, a critical mass will be reached were active faults sources may be used to enhance probabilistic seismic hazard analyses for long return periods. The data provided in this contribution provides important insight into what data is likely to be available in the Australian context, and what methodologies should be employed to make best use of it for hazard estimation. The most important implications of what we presently know, or can make an educated guess on, are summarised below.

In Eastern and Southern Australia, there are many fault scarps of known length and height for which evidence of Quaternary movement has been proposed. Perhaps the most easily quantifiable of these are the faults that bound the Flinders and Mount Lofty Ranges of South Australia ( $c f$. Bourman and Lindsay, 1989; Tokarev et al., 1998; Sandiford, 2003). On these faults, which support displacements of up to several hundred metres, the concept of recurrence of a characteristic event ( $c f$. Schwartz and Coppersmith, 1984) may be applicable. If slip rates were to be quantified for these structures, thus tying down long-term seismicity rates, the faults themselves may be modelled as earthquake source zones, as has been done in New Zealand (Stirling et al., 2002) and the United States (Frankel et al., 1996). A similar strategy could be applied to the Lake Edgar scarp in Tasmania (cf. McCue et al., 2003), the Cadell Fault in New South Wales ( $c f$. Bowler and Harford, 1964, 1966), and the many reportedly active faults in Victoria ( $c f$. Hills, 1960).

In contrast, the idea of recurrence of a characteristic event may not be applicable to scarps in Western and Central Australia. If the indications prove correct, and activity on these scarps is limited to one or two events before the system/segment is abandoned and seismicity migrates elsewhere, it is not appropriate to assign a characteristic magnitude event and use ruptured Quaternary faults themselves as active source zones for hazard assessment. Instead, an alternate approach similar to that used for the New Madrid seismic zone (e.g., Frankel et al., 1996) could be adopted. Rather than incorporating individual fault sources into the hazard framework, average parameters derived from faults in a region of concern could be assigned to synthetic source zones whose geometry is constrained by geologic data. Data from each Quaternary/Holocene fault within the region of concern could contribute towards defining parameters such as the maximum likely magnitude event for the region (or possibly characteristic event in some cases), typical source zone geometry, patterns of migration in seismicity, regional slip rates, and recurrence rates for surface rupturing events. These parameters are obtainable through paleoseismological investigation and have the potential to place important constraints on probabilistic hazard models. The immediate value of paleoseismological investigation in Central and Western Australia will be realised in the development of an understanding of the behaviour of the faults in this large portion of Australia.

\section{Concluding remarks}

The review of paleoseismological investigation presented in this contribution provides important insight into the nature of Australian intraplate seismicity, and a guide to how geologic data may be usefully incorporated in future revisions of the Australian seismic hazard map. Perhaps the most important realisation is that the methodologies employed to include active fault source zones into hazard assessment in New Zealand (e.g., Stirling et al., 1998, 2002) and the Western United States (e.g., Frankel et al., 1996) may not be appropriate for the Australian context. The limited data available indicate that Australian active faults are typified by return periods for surface rupturing events in the order of tens of thousands of years or more ( $c f$. Crone et al., 1993, 1997, 2003; Machette et al., 1993). If future investigations confirm this indication, each fault, when considered in isolation, is unlikely to contribute significantly to hazard for normal structures ( $c f$. the Meers Fault, Crone and Luza, 
1990). However, if other active faults are present in a region, as is certainly the case in the Flinders/Mount Lofty Ranges and in Eastern Australia, then the hazard is proportionately larger.

We put forward the hypothesis that the concept of recurrence of a 'characteristic' magnitude event on a single fault in the western and central parts of Australia may not be applicable, as there is no paleoseismological evidence, nor evidence in the landscape, of more than a couple of surface rupturing events on any given fault. In this context, estimates of hazard must be driven by an understanding of the patterns in migration of seismicity, and on an knowledge of the distribution of potentially seismogenic faults. Faults active in the Quaternary may not themselves contribute to the hazard, but can provide critical information on the long-term character of the seismicity in a region. This information can provide useful constraints on probabilistic hazard assessments.

Paleoseismology is still in its infancy in Australia. Many instances of known Quaternary faults that could provide valuable information on the character of Australian seismicity have not yet been investigated in detail. Because of the sparsely inhabited nature of the Australian continent it is very likely that more Quaternary and younger fault scarps will be found (in spite of high scarp degradation rates over much of arid Australia). Some of these may even relate to historic events. The future will involve devising methodologies to incorporate this geologic data into our hazard models, as has been done successfully in New Zealand and the United States. These methodologies will in part have to be uniquely Australian, to match the distinct character of Australian seismicity. This is our challenge.

\section{Acknowledgements}

Tony Crone and the Mike Machette of the USGS and Mike Dentith of the University of Western Australia are thanked for providing us access to unpublished data.

The authors thank John Schneider and Clive Collins for advice and comments on this manuscript. Kelvin Berryman and an anonymous reviewer are thanked for their helpful reviews. This contribution is published with the permission of the Chief Executive Officer of Geoscience Australia.

\section{REFERENCES}

Adams, J., R. Wetmiller, H. Hasegawa and J. Drysdale (1991): The first surface faulting from a historical earthquake in North America, Nature, 352, 617-619.

Adams, J., J. Percival, R. Wetmiller, J. Drysdale and P. ROBERTSON (1992): Geological controls on the 1989 Ungava surface rupture - a preliminary interpretation, Geol. Surv. Can. Pap., 92-C, 147-155.

AS1170.4 (1993): Minimum design loads on structures. Part 4: Earthquake Loads (Homebush NSW), pp. 64.

BouRMAN, R.P. and J.M. LINDSAY (1989): Timing, extent and character of Late Ceinozoic faulting on the eastern margin of the Mount Lofty ranges, South Australia, Trans. R. Soc. South Aust., 113, 63-67.

Bowler, J.M. and L.B. HARFORD (1964): Geomorphic Sequence of the Riverine Plain near Echuca, Aust. $J$. Sci., 26 (3), p. 88.

BOWLER, J.M. and L.B. HARFORD (1966): Quaternary tectonics and the evolution of the Riverine Plain near Echuca, Victoria, Geol. Soc. Aust., 13 (2), 339-354.

Bowman, J.R. and B.C. BARLOW (1991): Surveys of the fault scarp of the 1986 Marryat Creek, South Australia, earthquake, Geol. Geophys. (Bureau of Mineral Resources), Record 1991/109.

Bowman, J.R. and J.W. DEWEY (1991): Relocation of teleseismically recorded earthquakes near Tennant Creek, Australia - Implications for midplate seismogenesis, J. Geophys. Res., 96 (B7), 11,973-11,979.

Bureau of Meteorology (1995): Climatic averages Australia (Australian Government Printing Service, Canberra), pp. 932.

Carey, S.W. and G. Newstead (1960): Tasmania University Seismic Net, Publication 84, Geology Department, University of Tasmania.

Cherry, D.P. and R.W. NeIVAndt (1995): A Late Quaternary fault scarp on the Riverine Plain near Bendigo, Victoria, Unpublished Report (Geological Survey of Victoria).

Chin, R.J. (1985): Kellerberrin 1:250 000 scale, West. Aust. Geol. Surv., Geological Series Sheet Explanatory Notes, pp. 30 .

CHOY, G. and J.R. Bowman (1989): The rupture process of the 1988 Tennant Creek, Australia, earthquake from broadband teleseismic analysis, Geol. Geophys. (Bureau of Mineral Resources), Record 1989/6.

Clark, D.J. and M. LeONARD (2002): Principal stress orientations from multiple focal plane solutions: new insight in to the Australian intraplate stress field, in Evolution and Dynamics of the Australian Plate, edited by R.R. Hillis and D. Muller, Geol. Soc. Aust. Spec. Publ., 22, 85-99.

Clark, D.J., M. Dentith, K.-H. Wyrwoll, W. FeatherSTONE, L. YANCHOU and V. DENT (2001a): Palaeoseismological investigations on the Hyden fault scarp, Western Australia: towards a better understanding of the recurrence 
rate of large Australian intraplate earthquakes, in ILP2001 Conference Kaikoura New Zealand, 39-40.

Clark, D.J., M. Dentith, K.-H. Wyrwoll, W. FeatherStone, L. YAnchou and V. Dent (2001b): Australian paleoseismology: towards better earthquake hazard assessment, in Australian Earthquake Engineering Society Conference, Canberra: Earthquake Codes in the Real World, 10.1-5.

CoATs, R.P. (1963): The geology of the Alberga 4-mile military sheet (explanation of the geological map), Geol. Surv. South Aust., Report of Investigations 22, p. 22.

Cochrane, G.W., G.W. Quick and D. SPEnCER-Jones (1995): Introducing Victorian Geology, Geol. Soc. Aust. Victorian Division.

Connor, C.H.H. (Compiler) (1978): Witjuti, South Australia geologic map and photomosaic (northeast onequarter of the Eateringinna 100000-scale sheet), Geol. Surv. South Aust., Witjuti 5445-I, scale 1:50000.

Crone, A.J. and K.V. LuZA (1990): Style and timing of Holocene surface faulting on the Meers Fault, Southwestern Oklahoma, Geol. Soc. Am. Bull., 102 (1) 1-17.

Crone, A.J. and M.N. MACHETTE (1995): Holocene faulting on the Cheraw Fault, Southeastern Colorado - another hazardous Late Quaternary fault in the stable continental interior, Eos, 77 (Supplement, November 7, 1995), F362.

Crone, A.J., M.N. Machette and J.R. Bowman (1992): Geologic investigations of the 1988 Tennant Creek, Australia, earthquakes - Implications for paleoseismicity in stable continental regions, U. S. Geol. Surv. Bull., 2032-A, p. 51.

Crone, A.J., M.N. Machette and J.R. Bowman (1997) Episodic nature of earthquake activity in stable continental regions revealed by paleoseismicity studies of Australian and North American Quaternary faults, Aust. J. Earth Sci., 44 (2), 203-214

Crone, A.J., P.M. de Martini, M.N. Machette, K. OKUMURA and J.R. PRESCOTT (2003): Paleoseismicity of two historically quiescent faults in Australia Implications for fault behaviour in stable continental regions, Bull. Seismol. Soc. Am., 93 (5), 1913-1934.

DenHAM, D., and C.R. Windsor (1991): The crustal stress pattern in the Australian continent, Explor. Geophys., 22 (1), 101-105.

Denham, D., L.G. AleXANDER and G. WOROTNICKI (1979): Stresses in the Australian crust: evidence from earthquakes and in situ stress measurements, BMR J. Aust. Geol. Geophys., 4, 298-295.

DenhaM, D., J. WeEKES and C. KRAYSheK (1981): Earthquake evidence for compressive stress in the Southeast Australian crust, J. Geol. Soc. Aust., 28, 323-332.

Dentith, M.C., V.F. DenT and B.J. DRummond (2000): Deep crustal structure in the southwestern Yilgarn Craton, Western Australia, Tectonophysics, 325, 227-255.

DunHAM, M.H.R. (1992): The geomorphological nature and age of the linear escarpments of northeast Eyre Peninsula, Unpublished Ph.D. Thesis, University of Adelaide, SA

Electric Power Research Institute (EPRI) (1988): Seismic hazard methodology for the Central and Eastern United States, EPRI Report NP-4726, vols. 110.
Everingham, I.B. and L. TILbURY (1972): Information on Western Australian Earthquakes, 1849-960, West. Aust. R. Soc. J., 55 (3), 90-96.

Everingham, I.B., P.J. Gregson and H.A. Doyle (1969): Thrust fault scarps in the West Australian shield, Nature, 223, 701-703.

Frankel, A. (1995): Mapping seismic hazard in the Central and Eastern Unites States, Seismol. Res. Lett., 66, 8-21.

Frankel, A., C. Mueller, T. Barnhard, D. Perkins, E.V. Leyendecker, N. Dickman, S. Hanson and M. HopPER (1996): National seismic hazard maps, June 1996 documentation, U.S. Geol. Surv. Open-File Rep. 96-532.

GiardinI, D. (Editor) (1999): The Global Seismic Hazard Assessment Program (GSHAP) 1992-1999, Ann. Geofis., 42 (6), pp. 276.

Gordon, F.R. and J.D. LEwIS (1980): The Meckering and Calingiri earthquakes October 1968 and March 1970, West. Aust. Geol. Surv. Bull., 126, p. 229.

Gregson, P.J. (Compiler) (1990): Recent intraplate seismicity studies, in Conference Proceedings Perth W. A., BMR Record 1990/44.

HAmilton, R.M. and A.C. Johnston (1990): Tecumseh's prophecy: preparing for the next New Madrid earthquake. A plan for an intensified study of the New Madrid seismic zone, U. S. Geol. Surv. Circ., 1066, p. 30.

Hanks, T.C. and A.C. Johnston (1992): Common features of the excitation and propagation of strong ground motion for North American earthquakes, Seismol. Soc. Am. Bull., 82, 1-23.

HARRIS, W.M.J. (1938): The physiography of the Echuca District, in Proc. R. S. Victoria, 51 (1), 45-60.

Hills, E.S. (1960): The Physiography of Victoria (Whitcombe and Tomb, Melbourne).

Hillis, R.R. and S.D. Reynolds (2000): The Australian stress map, J. Geol. Soc. London, 157 (5), 915-921.

Hillis, R.R., J.R. ENEVER and S.D. REYNOLDS (1999): In situ stress field of Eastern Australia, Aust. J. Earth Sci. 46 (5), 813-825.

Hutton, J.T., J.R. Prescott, J.R. Bowman, M.N.E. Dunham, A.J. Crone, M.N. Machette and C.R. TwidAle (1994): Thermoluminescence dating of Australian Palaeo-Earthquakes, Quat. Geochronol., 13, 143-147.

Johnston, A.C. (1996a): Moment magnitude assessment of stable continental earthquakes, Part 2: historical seismicity, Geophys. J. Int., 125, 639-678.

Johnston, A.C. (1996b): Seismic moment assessment of stable continental earthquakes, Part 3: 1811-1812 New Madrid, 1886 Charleston, and 1755 Lisbon, Geophys. J. Int., 126 (2), 314-344.

Johnston, A.C. and G.D. SCHweIG (1996): The enigma of the New Madrid earthquakes of 1811-1812, Annu. Rev. Earth Planet. Sci., 24, 339-384.

Johnston, A.C., K.J. Coppersmith, L.R. KAnTER and C.A. CORNELl (1994): The earthquakes of stable continental regions, Electric Power Research Institute Rep. TR-102261-V1, Palo Alto, California.

KIERnAN, K. (1990): The Alpine Geomorphology of the Mt. Anne Massif, South-Western Tasmania, Aust. Geogr., 21, 113-125.

LAnger, C.J., M.G. Bonilla and G.A. Bollinger 
(1987): Aftershocks and surface faulting associated with the Guinea, West Africa, earthquake of 22 December 1983, Seismol. Soc. Am. Bull., 77, 15791601.

LANGSTON, C.A. (1987): Depth of faulting during the 1968 Meckering, Australia, earthquake sequence determined from waveform analysis of local seismograms, $J$. Geophys. Res., 92 (B11), 11,561-11,574.

LEONARD, M. (2002): The Burakin WA earthquake sequence September 2000 - June 2002, Australian Earthquake Engineering Society Conference, Adelaide: Total Risk Managements in the Privatised Era, proceedings volume, paper 22, 1-5.

LEONARD M., I. RIPPER and Y. Li (2002): Australian earthquake focal solutions, Geosci. Aust., Record 2002/19.

Lewis, J.D., N.A. DAETwYler, J.A. Bunting and J.S. MoncriefF (1981): The Cadoux earthquake, West. Aust. Geol. Sur. Rep. 11, p. 133.

Machette, M.N., A.J. Crone and J.R. Bowman (1993): Geologic investigations of the 1986 Marryat Creek, Australia, earthquake - implications for paleoseismicity in stable continental regions, U.S. Geol. Surv. Bull., 2032-B, pp. 29.

McCuE, K. (1990): Australia's large earthquakes and Recent fault scarps, J. Struct. Geol., 12 (5-6), 761-766.

McCue, K., B.C. Barlow, D. Denham, T. Jones, G. GiBson and M.O. MichaEl-LeibA (1987): Another chip off the old Australian block, Eos, 68 (26), 609-612.

McCue, K. B. Boreham, R. Van Dissen, G. Gibson, V. JENSEN and B. MCKavanagh (1996): A paleoseismology case study: the Lake Edgar Fault Scarp in Tasmania, Geoscience for the Community, in 13th Australian Geological Convention, Canberra, 19-23 February, 1996, Geol. Soc. Aust. Abstr., 41, p. 283.

McCuE, K.F. (1973): On the seismicity of Western Australia, Parts 1 and 2, Commonwealth Department of Works (Australia) Report

McCuE, K.F. (1975): Seismicity and seismic risk in South Australia, University of Adelaide Report ADP 137.

MCCuE, K.F. (1980). Magnitudes of some early earthquakes in South-eastern Australia, Search, 11 (3), 78-80.

McCuE, K.F. (2001): Do large earthquakes recur at the same place in Australia?, Aust. Earthquake Eng. Soc. Newsletter 3/2001, p. 6.

McCuE, K.F. and M.O. Michael-Leiba (1993): Australia's deepest known earthquake, Seismol. Res. Lett., 64 (3-4), 201-206.

McCue, K.F., M. Somerville and C. SinAdinovski (1998): The new Australian earthquake hazard map, in Proceedings of the Australasian Structural Engineering Conference, Auckland NZ, 1, 433-438.

McCue, K.F., R. VAn Dissen, G. Gibson, V. Jensen and B. BOREHAM (2003): The Lake Edgar Fault: an active fault in Southwest Tasmania, Australia with repeated displacement in the Quaternary, Ann. Geophysics, 46 (5), 1107-1117 (this volume)

MiLes, K.R. (1952): Tertiary faulting in Northeastern Eyre Peninsula, Trans. R. S. South Aust., 75, 89-96.

MYERS, J.S. and R.M. HocKING (1998): Geological map of Western Australia, 1:2500000, 13th edition, West. Aust. Geol. Surv.

Obermeier, S.F., P.J. Munson, C.A. Munson, J.R. Martin,
A.D. Frankel, T.L. Youd, and E.C. Pond (1992): Liquefaction evidence for strong Holocene earthquake(s) in the Wabash Valley of Indiana-Illinois, Seismol. Res. Lett., 63, 321-335.

PAlFREYMAN, W.D. (1984): Guide to the geology of Australia, Australia. ([Australia] Bureau of Mineral Resources), Geol. Geophys. Bull., 181, p. 111

QuitTMEYER, R.C. and K.H. JACOB (1979): Historical and modern seismicity of Pakistan, Afghanistan, Northwestern India, and Southeastern Iran, Seismol. Soc. Am. Bull., 69, 773-823.

QURESHI, I.R. and A.A. SADIG (1967): Earthquakes and associated faulting in Central Sudan, Nature, 215, 263-265.

Roberts, G.T., B.A. Cole and R.H.W. Barnett (1975): Engineering geology of Scotts Peak dam and adjacent reservoir watertightness, Aust. Geomech. J., 39-45.

SANDIFORD, M. (2003): Neotectonics of Southeastern Australia: linking the Quaternary faulting record with seismicity and in situ stress, in Evolution and Dynamics of the Australian Plate, edited by R.R. HiLLIS and D. Muller, Geol. Soc. Aust. Spec. Publ., 22, 101-103.

SCHWARTZ, D.P. and K.J. COPPERSMITH (1984): Fault behaviour and characteristic earthquakes: examples from the Wasatch and San Andreas Fault zones, J. Geophys. Res., 89 (B7), 5681-5698.

SeEber, L., S.K. Jain, C.V.R. Murty and N. ChandaK (1993): Surface rupture and damage patterns in the $M s=6.4$, September 29, 1993 Killari (Latur) earthquake in Central India, National Centre for Earthquake Engineering Research Bulletin, 7, p. 12.

SinAdinovski, C., T. Jones, D. Stewart and N. Corby (2002): Chapter 3: Earthquake history, regional seismicity and the 1989 Newcastle earthquake, in Earthquake Risk in Newcastle and Lake Macquarie, edited by T. DHU and T. Jones, Geosci. Aust. Record 2002/15, p. 271.

StirLing, M.W., S.G. Wesnousky and K.R. Berryman (1998): Probabilistic seismic hazard analysis of New Zealand, N.Z. J. Geol. Geophys., 41, 355-375.

Stirling, M.W., G.H. MCVERry and K.R. Berryman (2002): A new seismic hazard model for New Zealand, Bull. Seismol. Soc. Am., 92 (5), 1878-1903.

Тном, R. (1972): A recent fault scarp in the Lort River area, Ravensthorpe 1:250000 sheet, West. Aust. Geol. Surv. Annu. Rep. 1971.

Thom, R., S.L. LiPPLe and C.C. SANDERS (1977): Ravensthorpe, Western Australia 1:250000, West. Aust. Geol. Surv., Geological Series Explanatory Notes, 1st edition.

TiCKELL, S.J. and W.G. HumPHRYS (1987): Groundwater resources and associated salinity problems of the Victorian part of the riverine plain, Victoria Geol. Surv. Rep. 84.

ToKAREV, V., M. SANDIFORD and V. Gostin (1998): Landscape evolution in the Mount Lofty ranges: implications for regolith development, in Regolith 1998, 3rd Australian Regolith Conference, May 1998, Kalgoorlie Australia, edited by G. TAYLOR and C. PAIN, 127-133.

TwidAlE, C.R. (1968): Geomorphology with Special Reference to Australia (Thomas Nelson Aust. Ltd.)

Van Dissen, R., K.F. McCue, G. Gibson, V. Jensen, M. Somerville, B. Boreham, B. McKavanagh and A. GoEDE (1997): The Lake Edgar Fault: evidence for 
repeated Quaternary displacement on an active fault in Southwest Tasmania, in Proceedings of the 1997 Conference "Earthquakes in Australian Cities - Can we Ignore the Risks?», Brisbane 2-3 October 1997, Aust. Earthquake Eng. Soc., 5.1-5

Wells, D.L. and K.J. COPPERSMITH (1994): New empirical relationships among magnitude, rupture length, rupture width, rupture area, and surface displacement, Bull. Seismol. Soc. Am., 84, 974-1002.

WHITAKER A.J. and I.V. BASTRAKOVA (2002): Yilgarn Craton aeromagnetic interpretation, 1:1500000 scale map, Geosci. Aust.

WILLIAMS, G.E. (1973): Late Quaternary piedmont sedimentation, soil formation and palaeoclimates in arid South Australia, Z. Geomorphol., 17, 102-123.
WiLliams, P.R. (1977): Port Davey, Tasmania 1:250000, Geol. Surv. Tasmania, Geological Series Explanatory Notes, 1st edition.

WiLliams, I.R. (1979): Recent fault scarps in the Mount Narryer area, Byro 1:250000 sheet, West. Aust. Geol. Surv. Annu. Rep. 1978, 51-55.

Williams, I.R., I.M. WALKER, R.M. Hocking and S.J. Williams (1983): Byro, Western Australia 1:250000, West. Aust. Geol. Surv., Geological Series Explanatory Notes, p. 25.

YARwOOD, D.R. and D.I. Doser (1990): Deflection of oceanic transform motion at a continental margin as deduced from waveform inversion of the 1939 Accra, Ghana earthquake, Tectonophysics, 172, 341-349. 
